Journal of Policing, Intelligence and Counter Terrorism

\title{
An exploration of perceptions of real-life suspects' from the Asian Muslim community relating to the police interviewing practices in England
}

\section{Rashid Minhas, Dave Walsh \& Ray Bull}

To cite this article: Rashid Minhas, Dave Walsh \& Ray Bull (2017) An exploration of perceptions of real-life suspects' from the Asian Muslim community relating to the police interviewing practices in England, Journal of Policing, Intelligence and Counter Terrorism, 12:2, 158-174, DOI: 10.1080/18335330.2017.1355103

To link to this article: http://dx.doi.org/10.1080/18335330.2017.1355103

\section{曲 Published online: 11 Sep 2017.}

\section{Submit your article to this journal $₫$}

Q View related articles $\asymp$

View Crossmark data \lceil 


\title{
An exploration of perceptions of real-life suspects' from the Asian Muslim community relating to the police interviewing practices in England
}

\author{
Rashid Minhas, Dave Walsh and Ray Bull \\ International Policing and Justice Institute, One Friar Gate Square, University of Derby, Derby, UK
}

\begin{abstract}
In England and Wales, the 'war on terror' has been argued to impact adversely on existing race relations policies. New legislation (such as wide discretionary powers of stop and search and arrest under the Terrorism Act (TA) 2000, the extension of pre-charge detention of 28 days (TA 2006), and the use of control orders to detain without trial), policing, and counter-terrorism measures may cast Muslims as the 'enemy within'. The current research concerns real-life Asian Muslim suspects' perceptions and experiences of police interviewing practices in England. This study involves semistructured interviews with 22 people who had previously been interviewed as suspects throughout England. Around two-thirds of participants reported perceiving the demonstration of various stereotyping by police officers during interviews, half of whom indicated that the interviewers demonstrated racial/religious stereotypes via discriminatory behaviour. Given the potential and serious consequences of such racial/religious stereotypes and discriminatory behaviour, further training of police officers seems necessary to improve both interviewing performance and community cohesion.
\end{abstract}

\section{ARTICLE HISTORY}

Received 9 December 2016

Accepted 10 July 2017

\section{KEYWORDS}

Police interviewing; suspects; negative stereotypes

\section{Introduction}

Investigative interviews are one of the most important information-gathering tools employed by the police in the criminal investigation. During the last century, the police forces have used a variety of interviewing techniques. In England and Wales, police interviewing of suspects over the past 20 years or so has taken an apparently more ethical approach. Williamson (2006) describes that the purpose of all interviews in these countries is to search for the truth and to gather accurate and reliable information using non-coercive techniques.

The research concerning investigative decision-making suggests that police investigators rely on heuristics (a set of working rules) that they develop from conducting investigations or they learn from day-to-day experiences (Smith \& Flanagan, 2000). Under certain conditions, heuristics can lead to cognitive biases and mental errors (Rossmo, 2006). One heuristic that is used as an explanation for miscarriages of justice and failure 
of criminal investigations is 'tunnel vision' (Snook, \& Cullen, 2008). Tunnel vision is a product of multiple processes including cognitive distortions such as confirmation bias (Findley \& Scott, 2006). Confirmation bias towards suspects' wrongdoing during police interviews led to an 'accusatorial' style of interviewing, where police officers used a confirmatory strategy to elicit confessions (Mortimer \& Shepherd, 1999). It has been found that expectations of guilt led to interviewers: (i) asking more guilt-presumptive questions; (ii) conducting persistent and coercive forms of questioning; and (iii) exerting more pressure on suspects to confess, which may result in or contribute to false confessions (Kassin, Goldstein, \& Savitsky, 2003).

The quality of an investigative interview could be affected by police officers' personal perception of people, places, and situations. Racism, sexism, and homophobia are all wellknown biases that could affect the thought process without the individual realising that he/she is having such biases (Stelfox, 2009). One of the most concerning types of biases within the criminal justice system may well be prejudicial stereotypes about a group (Huggon, 2012). Focus of such bias can be on race or ethnicity, but can also include bias against someone based on his/her group membership. Prejudicial stereotypes are generally thought to be one of the prominent sources of partiality in criminal trials (Huggon, 2012).

In his seminal text, Allport (1954) viewed attitudes, beliefs, and behaviours as separate but interrelated components of prejudice. According to Allport (1954), an attitude is a mental and neural state of readiness, organised through experience, exerting a directive and dynamic influence upon the individual's response to all objectives and situations with which it is related and a belief is based on overgeneralisation or erroneous information. Allport (1954) suggested that prejudice is an inevitable and therefore common consequence of the ordinary categorisation (stereotyping) process. Prejudice involves negative feelings towards people based on their group membership, whereas stereotyping involves negative beliefs and thoughts about such groups (Blaine, 2012). Both negative stereotyping and prejudice are features that have been found to adversely affect police officers' search for the truth (Huggon, 2012; Williamson, 2006), being the official and stated aim of police interviews in England and Wales under PACE (Police and Criminal Evidence Act 1984) legislation.

Police officers are generally native-born citizens, who have been long exposed to their local, social, and cultural surroundings, forming stereotypes from their society's collective knowledge and beliefs (Smith \& Alpert, 2007). Whether such negative stereotypes operate consciously or unconsciously, it has been argued that such negative stereotypes are more likely to further develop through repeated contacts with perceived out-groups (Smith \& Alpert, 2007). Police work involves frequent interaction with poor, minority, and socially disadvantaged groups (Maynard-Moody \& Musheno, 2003), developing negative stereotypes based on such repeated exposure (Smith \& Alpert, 2007).

The present study examines the impact of any negative stereotypes within the context of investigative interviewing considering the term 'suspect community' stereotyping. This study considers Hillyard's (1993) first application of the term 'suspect community' to the Irish in United Kingdom in the era of Prevention of Terrorism Act (PTA) and its more recent application to Muslims in the global 'war on terror' (Breen-Smyth, 2014; Pantazis \& Pemberton, 2009). A 'suspect community' is created in and by the scrutinised 
imagination and enacted in a process of 'othering' through a range of security practices of counter-terrorism (Breen-Smyth, 2014). Hickman, Thoms, Silvestri, and Nickels (2011) found that parallels existed between those experiences of people from the Irish community in the 1970s and those from the Muslim community today with regard to the way they are treated by police in England and Wales. Whether accidentally or not, measures such as profiling, hard-line policing, stop and search, and surveillance all have the potential to stigmatise the entire population, such as Irish people during the conflict in Northern Ireland, and now the Muslim community in Britain (Awan, 2012). When a community is stereotyped as suspects in public discourse and the state response becomes ever more draconian that inevitably has a damaging effect on criminal justice system and to the very society that it is intended to protect (Clements, 2008).

Over the past three decades, specific stereotypes have been commonly used by police officers to classify people on the basis of their ethnic origin (Bowling \& Phillips, 2003). Hence, police officers may nonetheless base their decisions on beliefs about group criminality and who is most likely to be involved in crime (Smith \& Alpert, 2007). It has been found that the pliability of stereotypes of Asian and particularly Muslims has been documented in recent research, which has suggested that stereotypes of Asians and particularly Muslims have undergone a transformation since 'war on terror' (Phillips \& Bowling, 2003). Following the terrorist attacks of 11 September 2001 in the U.S., 11 March 2005 in Madrid, and 7 July 2005 in London, the position of Muslim youth in the United Kingdom has fundamentally changed and the assumptions around Muslim youth in Europe has become more generalised (Lynch, 2013). A striking outcome of these terrorist attacks is that of the increased antipathy, prejudice, and discrimination experienced by Muslims who are stereotyped on the basis of what an extremely small number of terrorists have done (Clements, 2008).

In the past, such negative stereotypes have contributed to the grave violations of human rights with tragic consequences that involved miscarriages of justice. For example, when the police in England and Wales interviewed Irish suspects (e.g. the Birmingham Six and the Guildford Four), where these suspects confessed under police pressure to serious crimes later found that they did not commit. Police officers were found to be biased against such suspects, suspecting that they were responsible for bombings merely because they belonged to an Irish Community (Pantazis \& Pemberton, 2009). This indicates that negative stereotyping could result in criminal investigation failures which primarily exist within police interviewing context (Milne \& Bull, 1999).

Minhas, Walsh, and Bull (2017) found five core components of prejudicial stereotyping in investigative interviewing. These components include (i) possessing negative perceptions; (ii) use of schemas; (iii) guilt presumption; (iv) self-fulfilling prophecy; and (v) hostile approach. They subjected these components to Guttman scalogram analysis to examine the cumulative structure of the components to develop a scale called the Minhas Investigative Interviewing Prejudicial Stereotyping Scale (MIIPSS). They concluded that constructs in the MIIPSS met the requirements of a valid Guttman scale, indicating that patterns of items are cumulative which suggests that police interviewers' attitudes might eventually be transformed into a hostile approach if they hold negative stereotypes towards suspects based on their group membership such as ethnicity, race, belonging to particular area and particular crime type. Given the identification of five constructs of 
MIIPSS, the present study conducted deductive analysis in order to examine the police interviewers' attitudes as perceived by interviewees.

Social identity theory offers a powerful explanation for the social foundation of stereotypes. Social identity theory maintains that group membership serves to bolster selfesteem, and thus, individuals have an incentive to favour in-group members (their own) over out-groups members (see Tajfel \& Turner, 1979, for more details). Thus, people create positive social identities that are linked to group membership and tend to view their own social groups more positively than the other groups. When social identities centre around race and ethnicity, the result can be negative racial stereotypes that are reinforced by group beliefs and interactions (Smith \& Alpert, 2007). The role of negative stereotypes within the context of police interviews with suspects has received negligible attention. As police officers too are drawn from society, they may equally possess negative feelings towards suspects from certain groups, affecting their thought processes, exhibited in their questioning style when conducting interviews with suspects from certain groups (Minhas et al., 2017). As such, given the identification of prejudicial stereotyping in investigative interviewing, the present study aims to explore the real-life Asian Muslim suspects' perceptions and experiences when police interviewers undertook the task of interviewing them as suspects of a crime.

\section{Method}

\section{Participants}

The present study used in-depth interviews with 22 people from the Asian Muslim community who had been previously interviewed by police on at least one occasion as a suspect of a crime. The 22 participants (all males), were from four major English cities (Bristol, London, Manchester, and the West Midlands). Sixteen of the participants were born in England and the remaining six were migrants. Each had been last interviewed by the police as a suspect of crime on at least one occasion between 2010 and 2014. Participants' ages ranged from 18 to 50 years $(M=31.32, S D=9.48)$. Fourteen of the participants were interviewed over matters relating to a single offence, eight of the participants were interviewed on more than one occasion relating to single or multiple offences. Eleven of the participants were convicted for the offences that they were last interviewed about, five were released without charge, while the remaining six were still waiting for trial at the time of conducting the present study. None of the participants was believed to be known to each other. None was given any incentive or reward for their participation. The details of each participant's index offence(s) are shown in Table 1.

\section{Procedure}

The participants were contacted through the first author's associates, who were requested if they knew anyone who had been interviewed by police within the last five years as a suspect of a crime. They passed the first author's mobile number to the suspects (or on occasion, the suspects' numbers were passed to the first author). From these contacts, the first author was successful in securing agreement to interview 16 participants. The 
Table 1. Index of suspected offences of the 22 participants.

\begin{tabular}{|c|c|c|c|c|c|}
\hline $\begin{array}{l}\text { Participant } \\
\text { No. }\end{array}$ & Interview year & $\begin{array}{c}\text { Age on } \\
\text { event }\end{array}$ & $\begin{array}{l}\text { No. of times } \\
\text { interviewed }\end{array}$ & City & Index suspected offences \\
\hline 01 & 1999, 2011 & 18,30 & 2 & West Midlands & Drugs/Suspected terrorism \\
\hline 02 & 2013 & 17 & 1 & West Midlands & $\mathrm{GBH}$ \\
\hline 03 & 2012 & 18 & 1 & West Midlands & Drugs (intent to supply) \\
\hline 04 & 2014 & 24 & 1 & London & Human trafficking \\
\hline 05 & 2006,2010 & 34,38 & 2 & West Midlands & GBH, Attempted murder \\
\hline 06 & 2014 & 46 & 1 & London & Dangerous driving/Drugs \\
\hline 07 & 2011 & 18 & 1 & West Midlands & Drugs \\
\hline 08 & 2014 & 48 & 1 & Greater Manchester & Aiding a rape \\
\hline 09 & 2014 & 30 & 1 & Greater Manchester & Fraud/Money laundering \\
\hline 10 & 2014 & 32 & 2 & London & Fraud/Money laundering \\
\hline 11 & 2011, 2014 & 43,46 & 2 & West Midlands & Suspected terrorism \\
\hline 12 & 2014 & 24 & 1 & London & Sexual assault \\
\hline 13 & 2014 & 26 & 1 & London & Sexual assault \\
\hline 14 & 2011 & 35 & 2 & London & Human trafficking/money laundering \\
\hline 15 & 2011, 2014 & 30,33 & 3 & West Midlands & Drugs (intent to supply) \\
\hline 16 & 2011 & 19 & 1 & West Midlands & Sexual assault \\
\hline 17 & 2013 & 26 & 1 & Bristol & GBH \\
\hline 18 & 2012 & 34 & 1 & West Midlands & $\mathrm{GBH}$ \\
\hline 19 & 2014 & 18 & 1 & West Midlands & Drugs (intent to supply) \\
\hline 20 & 2013 & 28 & 3 & West Midlands & Suspected terrorism \\
\hline 21 & 2014 & 21 & 1 & Bristol & Drugs \\
\hline 22 & 2014 & 19 & 2 & Greater Manchester & Money laundering \\
\hline
\end{tabular}

first author requested a further associate, a criminal lawyer, to ask some of his clients if they would agree to take part in the current study. A further six participants were sourced through this route.

Having received ethical approval from his home University, the first author arranged meetings with each of the participants duly conducting semi-structured interviews in public places (for example, cafes and restaurants) throughout January-May 2015. All the participants were informed that interview would be audio recorded (if they consented), and that they were assured anonymity, provided they did not make any indications to commit further offences or did not disclose information about a crime they had committed for which they had not yet been convicted. Twenty participants provided consent for their interviews to be audio recorded (the other two agreed only to notes being taken of the interview manually). Participants first were asked to provide their own interpretations of their range of experiences and perceptions during an interview about the police interviewers' attitudes towards them. Each participant was asked the same standard set of questions, though where necessary, elaboration and clarification were provided.

\section{Analytical framework}

The present study employed a thematic analysis of interview transcriptions. Thematic analysis differs from other qualitative analytical methods that seek to illustrate patterns across the data, such as thematic discourse analysis, grounded theory (GT), and interpretative phenomenological analysis (IPA) (Braun \& Clarke, 2006). One of the advantages of thematic analysis is its theoretical freedom and it can be either inductive (data-driven) or deductive (theory-driven). Thematic analysis is chosen for current study in order to access both (i) inductively (with themes emerging from surface meaning of the data) 
(Boyatzis, 1998); and (ii) deductively (i.e. examining the five constructs of MIIPSS) (Crabtree \& Miller, 1999) the perceptions and experiences of suspects about their police interviewers' attitudes towards them during interviews. As such, inductive analysis is a process of coding the data without trying to fit it into a pre-existing coding frame. In contrast, deductive analysis would tend to be driven by the researcher's theoretical or analytical interest in the area and is thus more explicitly analyst-driven (Braun \& Clarke, 2006). In this study, the codes were accordingly both inductive and deductive, originating both from the authors' theoretical understandings and from the participants themselves (Miles \& Huberman, 1994).

\section{Inductive analysis}

In the present study, the inductive analysis took a semantic or explicit approach (Boyatzis, 1998), that is, the themes were identified from the 'explicit or surface meaning of data' (Braun \& Clarke, 2006, p. 84). The first step of the analysis involved an initial reading of the transcribed interviews to gain familiarisation with the data. In the second reading, a line-by-line coding was undertaken ascribing each sentence a code that described the main essence of the sentence. In this study, to code the data, the guidelines for conducting thematic analysis constructed by Braun and Clarke (2006) were followed. Initially, all the data were coded and codes were merged into larger units organising those that seemed similar in meaning content. This was followed by sorting the different codes into potential themes and collating all the relevant coded data extracts within the identified themes and sub-themes for each interview. In the present study, a theme was defined as the smallest unit that in a meaningful way could express the codes that were included in it. From the individual summary sheets, an overall list of themes was constructed. Themes were refined and grouped into clusters to form following two super-ordinate themes; (i) the legal framework underlying the police interview context; and (ii) participants' perceptions about the interviewing practices.

\section{Deductive analysis}

This approach to thematic analysis was employed by the authors to examine the attitudes of the interviewers as perceived by the participants. For the purposes of deductive analysis, five constructs of MIIPSS (Minhas et al., 2017) were regarded as priori category and therefore the method used was category allocation. The five constructs of MIIPSS are: (i) possessing negative perceptions; (ii) use of schemas; (iii) guilt presumption; (iv) self-fulfilling prophecy; and (v) hostile approach. The first author read through each interview transcript and, using these five constructs as coding categories, ascertained whether any of these constructs were evident in each transcript. Essentially, the analysis was identifying the themes evident in the transcripts, consulting the description of each construct (as defined in Minhas et al., 2017), and judging as to whether or not there was any evidence in the transcripts of a specific construct. The examination of each construct is given in Results section under the super-ordinate theme of 'perceived attitudes of the interviewers'.

\section{Inter-rater reliability}

Following the coding process of transcriptions, authors invited an independent Ph.D. researcher with established knowledge of thematic analysis to code the randomly selected 
10 copies of transcriptions. The rater worked with clean copies of transcriptions independently and had no knowledge of first author's coding results. The inter-rater reliability of identification of above three themes (i.e. the legal framework underlying the police interview context, participants' perceptions of interviewing practices, and perceived attitudes of the interviewers) was examined using the Cohen's kappa. It was found that a Cohen's kappa 0.91 existed between the two sets of scores, demonstrating a strong strength of agreement (Fleiss, 1981).

\section{Results}

The findings are discussed and presented under these main themes; (i) the legal framework underlying the police interview context; (ii) participants' perceptions of interviewing practices; and (iii) perceived attitudes of the interviewers. An analytical narrative was constructed and extracts from the transcripts are presented to illustrate each of the three super-ordinate themes.

\section{The legal framework underlying the police interview context}

This super-ordinate theme is comprised of two sub-themes which are consistent with the participants' perceptions concerning the legal framework surrounding the police interviews. These sub-themes are; (i) Section 76 and Section 78 of PACE; and (ii) explaining the legal procedures.

\section{Section 76 and Section 78 of PACE 1984}

Section 76 of PACE deals with challenges to the admissibility of confessions and directs the court to exclude confession evidence obtained by oppression, in circumstances which were likely to make the confession unreliable. Section 78 of PACE provides further safeguard against police malpractice. It allows the courts to exclude any evidence which would otherwise be admissible against a defendant felt to have been unfairly induced. All of the participants did not describe any instances which evidently indicated any violation of either Section 76 or Section 78 of PACE. For example, Participant (08) stated,

I was given time to comment. They treated me alright, they didn't misbehave towards me.

All the participants shared a common view that they were treated better during the interviews as compared to during their arrest and during custody arrangements.

\section{Explaining the legal procedures}

All the participants reported that at the beginning of the interview, police interviewers explained the purpose of the interview and clearly mentioned what legal rights they (as suspects) had. For example, Participant (16) reported,

I mean, the initial questions were making sure I understood my charges, why l'd been brought there and what rights I had, you know, like the right to remain silent and the right to legal representation 


\section{Participants' perceptions of interviewing practices}

This super-ordinate theme is comprised of three sub-themes which are consistent with the participants' perceptions concerning techniques employed by the police interviewers during the interviews. These sub-themes are: (i) participants' perceptions of their interviewers' communication with them; (ii) effects of evidence on participants' denials and confessions during interviews; and (iii) use of tactics employed by the interviewers as perceived by the participants.

\section{Participants' perceptions of their interviewer's communication with them}

Sixteen of the participants described their experience of being interviewed by the police interviewers as an uncomfortable and unfriendly event. Participant (16) reported,

They started off with the whole what my rights are, what I can do, what I can't do and then straight away they got into it, right you've been arrested for ....

Whereas participant (06) stated,

No, I mean, like I said, it was all done professionally. At no point was anybody overly aggressive to me, but they weren't placid either. It was, sort of, right tell us, you know, what you have got to say for yourself basically.

\section{Effects of evidence on participants' denials and confessions during interviews}

Six of the participants perceived that the evidence held by the police against them was strong. Five of these particular participants stated that they made no attempt to deny their guilt to the police. These participants described a common reason for confessing guilt was a belief that the police officers would be able to prove their guilt due to strong evidence against them. Participant (06), perhaps, best encapsulates this,

I was caught in the act ... I mean, I can say this ... I was guilty and I did go in with guilty plea

... it was a mistake that is what's happened, nothing, yes, I wanted to confess to it.

Participant (22) stated he initially denied his guilt but when he believed that the police had enough evidence to prove him guilty, he decided to confess.

but then when they come out with the evidence I knew that if I carried on lying I'm going to get sent to trial and I'm going to get, like, extra years on my sentence, but then obviously they sorted it out of Crown Court, they go just knock it down to two if you plead guilty and obviously reduce my sentence ..., I just admitted to everything, I goes, yes, I done it.

Sixteen of the participants believed that the evidence against them was either very weak or did not exist at all. Importantly, these are the participants, who also mentioned that police officers were not friendly towards them. These participants stated that police interviewers exerted pressure and wanted them to confess when they were not involved in any wrongdoings or evidence against them was either very weak or did not exist at all. For example, Participant (11) said,

There was no evidence against me, evidence didn't exist. It was one-way traffic. They tried to contain me and re-enforce their version. 


\section{Tactics employed by the interviewers as perceived by the participants}

Fourteen of the participants perceived that the questioning during the interview was dominated by repetitive and guilt-presumptive questions. These are the participants who also indicated that there was a lack of rapport and perceived that the evidence against them was weak or did not exist at all. For example, Participant (05) reported,

When you come in there, you're already, like you had been charged already. It shouldn't be like that. I should have a chance to express myself and of give my event of what happened.

A number of these participants stated that police interviewers exerted pressure on them during interviews. Participant (22) described,

Yes, twisting the questions and twisting my words. If I'm saying something he'll twist it saying that he didn't just say something else then he wants me to say what he's saying, but it didn't work and then I start shouting a bit.

Nevertheless, eight of the participants stated that police interviewers asked relevant questions. Participant (13) stated,

They (police interviewers) were interested in getting my part of the story. They didn't try to accuse me or treated me badly.

These particular participants emphasised that purpose of the questioning throughout the interview seemed to know their part of the story.

\section{Perceived attitudes of the interviewers}

This super-ordinate theme is comprised of five sub-themes which are consistent with the participants' perceptions concerning the police officers' attitudes towards them. These sub-themes are: (i) possessing negative perceptions; (ii) use of schemas; (iii) guilt presumption; (iv) self-fulfilling prophecy; and (v) hostile approach.

\section{Possessing negative perceptions}

The interview could possibly be affected by the interviewer's negative perceptions if one or more of the following indicators were identified by the participant as present during the interview; (i) the interviewer's perceived attitudes towards interviewee were negative; (ii) there was a lack of empathy; and (iii) there was an absence of good relationship (or rapport) between the suspect and the interviewer (Minhas et al., 2017). When reflecting their perceptions of police officers' attitudes, 17 of the participants (81.8\%) believed that police officers' perceived attitudes towards them were negative. The majority of these participants perceived that the police interviewers were unfriendly during the interview and their attitudes were biased towards them. For instance, Participant (02) stated,

They're always biased and negative towards you because obviously, they're interviewing you.

They want you to fall in their trap, isn't it? In the interview, they're negative all the way.

\section{Use of schemas}

The interviewer could possibly use schemas to support his/her existing beliefs if the participant perceived that interviewer's negative attitudes towards him were due to one or 
more of the following; (i) his/her group membership; (ii) his/her race; (iii) his/her religion; (iv) the particular nature of the crime (such as sexual crimes, paedophilia or drugs-related crimes); or (v) his/her previous criminal record (previously known to the police) (Minhas et al., 2017). Just over two-thirds of the participants (68.2\%) stated a number of reasons for police officers' negative behaviour towards them including: (i) previously being known to the police; (ii) ethnicity; (iii) religion; (iv) police culture; and (v) specific crimerelated location.

Previously being known to police: of the participants, who have been interviewed by the police on more than one occasion, five mentioned that the police officers' perceived negative attitudes towards them could have been due to their previous criminal record. For example, participant (22) stated,

I've had a case where I've been beaten up by a gang and I've been hurt, wounded and I've taken the case to the police, they didn't take it any further. They said this case can't go to court. Even though I had a witness they said we can't take it to court, we don't trust you, because of your criminal record.

Ethnicity: thirteen of the participants stated that the police officers' perceived negative attitudes towards them could be due to their ethnicity. Participant (21) stated,

There's a certain mindset or there's a certain belief system, you know, amongst some of the police officers which actually they feel that you know, perhaps people of like Asian background ethnicity are the enemy, are the criminals.

Religion: seven participants felt that police interviewers' perceived negative attitudes towards them could possibly be due to their religious background. Participant (07) reported,

Yes, as I mentioned before the one officer, you know, when he was saying things like your kind or your type of person and, you know, it was fairly obvious that he was discriminating. But, then afterward it became apparent to me when he made a comment that l'd rather interview a Bob over an Abdul any day. It became very apparent that it had to do with my race, so it was very clear at that point.

Participant (17) claimed he was wrongly accused and falsely convicted of a serious offence. He further described that at one stage of investigation he became so scared that police officers may link him with terrorism offences due to his religious background. He stated,

The overall attitudes of the police interviewers were very negative towards me, they were committed to proving me guilty and they wanted to send me to prison. And this was mainly due to my Islamic background and sporting a beard. That's why I became so scared that they would link me with terrorism.

Police culture: four participants thought that it is within the police culture to hold negative attitudes towards anyone who is suspected of committing a crime. Participant (09) stated,

That's the way they're brought up in the camp. Even if it's an Asian police officer it's the same attitude. If he's white or black or whatever, they've all got the same attitude. It's the uniform. It's the power and that's why.

Specific crime-related location: five participants described that police officers could potentially hold negative attitudes if an individual is of Asian descent and the alleged crime is drug-related in a particular location. For example, participant (16) reported, 
Basically, I lived in a very Asian area and the area was known to have problems with the police, you know, drug dealing happens everywhere, because it was an Asian area it was that sort of profile they had ... . I was a student. I was doing a law degree myself at the time, but they didn't even know any of that. As far as they were concerned and what it felt like was just another guy brought off the street and they weren't willing to even talk to me.

\section{Guilt presumption}

The interviewer could possibly have presumed the suspect guilty if one or more of the following indicators were identified by the participant as present during the interview: (i) the interviewer asked guilt-presumptive questions (i.e. questions displaying the interviewer's confirmation bias) (ii) the interviewer asked provocative questions (iii) the interviewer demonstrated bluffing tactics; (iv) the interviewer demonstrated inflexibility (e.g. interviewers did not adjust their stance in light of new information received from the interviewee); or (v) the interviewer reacted to the suspect's behaviour with destabilising, disturbing or confusing (non-verbal) responses (Minhas et al., 2017).

Fourteen participants $(63.6 \%)$ perceived that the police officers presumed them guilty of the suspected crime from the very beginning of the interview. Many stated that after explaining the legal procedures, the police officers asked them questions to prove them guilty. For instance, Participant (05) reported,

Like as soon as we (participant and his legal representative) came in, they treated us like as we were guilty of the crime, not given us a chance to prove our innocence. When we went to the interview, they started throwing the questions at us, instead of listening to us, when we should have a bit more chance for them to understand the story.

These participants reported that the police officers repeatedly asked them guilt-presumptive questions. Participant (09) reported,

No, because they kept asking the same question and then he starts raising his voice, so you know that he wants to get it out of you, but if I don't know the truth then how can I tell them something.

\section{Self-fulfilling prophecy}

The interview could possibly be affected by interviewers' self-fulfilling prophecies if one or more of the following indicators are present during an interview; (i) interviewer overweighed the evidence; (ii) the interviewer ignored evidence that could have gone in the suspect's favour (or at least not led to the belief of guilt); (iii) the interviewer maximised or minimised the nature of offence; (iv) the interviewer repeatedly accused the interviewee of the crime(s); and (v) the interviewer repetitively asked leading questions (Minhas et al., 2017).

Ten participants (45.5\%) perceived that the police officers (i) exaggerated the evidence; (ii) ignored the evidence that could have gone in their favour (or at least not led to the belief of guilt); (iii) maximised the nature of the offences; and (iv) repeatedly accused them of the crime. A number of these participants described the police officers' presumption of guilt even though there was no evidence to connect them to the crime. These participants perceived that the police officers still tried to connect them to the crime with 'irrelevant' evidence. For example, Participant (06) described, 
See ..., because they did search my house, you know, and they found a few things which were totally irrelevant, was totally not connected to the crime at all. But, I felt that they were trying to make links. Make links which are stupid links and I just laughed. It's just, like, trying to make mountains out of molehills. That's why, you know, CPS $^{1}$ didn't even bother taking it seriously $\ldots$. .

Many of these participants reported that the police officers were so fixated on charging them that they ignored the evidence, which could have gone in their (interviewee) favour. Participant (5) reported,

All the evidence was short, CCTV, that was missing. They presented the evidence which was all against me and nothing in my defence. My solicitor asked for that but we never got it. I don't know what circumstances, maybe it was what colour I am, ethnicity group I am or maybe they just like that, they trying to get all the evidence against me.

\section{Hostile approach}

The interviewer's approach could possibly be considered as hostile if one more of the following indicators are present during an interview: (i) interviewer's behaviour appears oppressive (e.g. instances of undue pressure, bullying, or continual challenge); and (ii) asked persistent and coercive questions during the interview (Minhas et al., 2017). Eight of the participants $(36.4 \%)$ stated that the police officers had demonstrated hostility towards them during the interview. For instance, participant (17) described,

He kept repeating the question about the diary, again and again, I started smiling. The police officer shouted, stop smiling, I am serious about these questions. My solicitor intervened. The police officer lost his temper with him too and shouted, you don't need to intervene, let the suspect talk. Then they stopped the interview.

When reflecting on the police officers' attitudes during interviews, a couple of participants described it as aggressive and threatening. Participant (06) described,

Because he was losing his cool, you know his posture. I noticed he started leaning back, you know, raising his chin, raising his voice, and he started flapping his hands about and stuff, you know. It wasn't very pleasant. He came across very aggressive. I do remember at one point he slammed his fist on the table, do you understand?

\section{Discussion}

The present study sought to examine Asian Muslim suspects' perceptions as to whether police interviewers appear used negative stereotypes towards them and whether they employed tactics that are not in line with the current ethos of police interviewing practices in England and Wales (as outlined in the PACE Code C). It was also examined if these suspects perceived whether police interviewers displayed negative stereotypes towards them, and (if they did), to what extent did these perceived negative stereotypes transform into discriminatory behaviour?

From the findings (relative to the legal framework underlying the police interview context), it appears that police interviewers are thoroughly aware of the importance of legal and procedural issues. The PACE Act legally imposed, a standardised and structured set of procedures to which the police interviewers must adhere or risk the interview being ruled inadmissible in court. All the participants stated that at the beginning of the 
interview the police officers explained the purpose of the interview and clearly mentioned what legal rights they had. The participants shared a common view that they were treated better during their formal interviews when compared to those interactions upon their arrest or during custody arrangements. It appears that the general standards of police interviewing have improved since the introduction of PACE, in terms of legal and procedural issues, similar to the findings of earlier studies (for example, Clarke \& Milne, 2001; Clarke, Milne, \& Bull, 2011; Griffiths \& Milne, 2006; Walsh \& Milne, 2008).

Further findings (relative to participants' perceptions of interviewing practices) suggest that during those interviews, where poor communication (rapport building) was demonstrated, police officers (as perceived by the participants) tended to directly or indirectly accuse the suspect right after explaining the legal procedures. In such interviews, the participants perceived their experience as an uncomfortable event, indicating an unfriendly atmosphere of communication. This finding suggests that such interviews may well have been lacking a good foundation for an open and detailed conversation, which is the underlying principle of investigative interview model in which police officers are trained. In their study, Walsh and Bull (2012) found those interviewers, who were rated either as being satisfactory or skilled in their rapport building skills were three times as likely to achieve a comprehensive account from the interviewees compared to those assessed as either unsatisfactory or poor. In the present study, it was found that just less than two-thirds of the 22 participants indicated a lack of rapport during the interviews. Since Walsh and Bull (2012) found poor rapport building is associated with an increased risk of police interviewers failing to elicit comprehensive and reliable accounts from interviewees (being the stated aim of police interviews in England and Wales). Therefore, the present study suggests that police interviewers are obtaining incomplete accounts (i.e. they lack information/evidence that might well assist in helping to determine either innocence or guilt).

Furthermore, in cases where participants perceived that the evidence against them was strong, it was more likely that they would confess to their guilt. Conversely, where the participants believed or perceived that the evidence against them was weak (or did not exist), they denied their involvement and refuted such accusations. It was also found that when the participants perceived that the evidence was weaker, the interviewers tended to repeat the original accusations which generally prompt further denials from the participants, similar to the findings in the study conducted by Moston, Stephenson, and Williamson (1992).

The third qualitative theme of prejudicial stereotyping is unique to this study. When reflecting their views on police officers' attitudes, the majority of participants (81.8\%) perceived that police interviewers' attitudes towards them were negative. These participants perceived that the police officers' negative attitudes towards them were due to either (i) their being previously known to the police (31.8\%); (ii) their ethnicity (59.1\%); (iii) their religion (31.8\%); (iv) police culture (13.6\%); or (v) the specific crime-related location $(22.7 \%)$. Such a fixed over-generalised belief about a particular group of people or class of people is known as stereotypes (Cardwell, 2000).

Collective findings from the current study and the previous literature (Devine, 1989; Huggon, 2012; Tajfel \& Turner, 1979) indicate the use of negative stereotypes (i.e. previously being known to police, ethnicity, religion, specific crime location) may have adverse effects on such interviews as these stereotypes can have a more negative 
effect when interviewing suspects from minority (out-groups) communities. As such, negative stereotypes may well be one of the most dangerous types of biases to the criminal justice system and the focus of such negative stereotypes can be on race or ethnicity (Huggon, 2012). Devine (1989) found that as long as stereotypes exist, prejudice will follow it and is inevitable. Social identity theory offers a powerful explanation for the social foundation of such stereotypes. Social identity theory maintains that group membership serves to bolster self-esteem, and thus, individuals have an incentive to favour in-group members (their own) over out-group members (see Tajfel \& Turner, 1979, for more details).

To what extent can negative stereotypical attitudes result in discriminatory behaviour? As such, nearly two-thirds of participants perceived that police interviewers asked them guilt-presumptive questions and they felt that this was because of such negative stereotypes. Previous studies found that guilt-presumptive questions produce a self-fulfilling prophecy effect (for further details, see Hill, Memon, \& McGeorge, 2008; Kassin et al., 2003). It was found that nearly half of participants perceived that their interviews could be affected by police officers' self-fulfilling prophecies. Consequently, this approach (that involves guilt presumption and self-fulfilling prophecy effects) may have led to the interviewer demonstrating hostility or discrimination towards suspects (Minhas et al., 2017). It was also found that a third of the participants mentioned the instances of interviewers' discriminatory behaviour. It is also important to recognise that some of the unsatisfactory findings pertain not to race/religion but may well be due to mishandling by the police and probably would have been voiced regardless of ethnicity/religion.

\section{Limitations and future directions}

Semi-structured interviews for assessing participants' perceptions are prone to error resulting from cognitive and motivational biases as they are reliant on participants' self-report (Ehrlich \& Rinehart, 1965). During the semi-structured interviews, suspects may have exaggerated their responses or their responses could have been affected by their own personal biases against the police. To mitigate any bias effects, the first author made sure that none of the participants was recruited by any other of the participants in the present study, (that is, all the participants were known neither to each other nor to any of the authors). Additionally, since the participants were recalling events of up to five years prior to their interview in the present study, it is possible that some of those memories might have been affected by such a time delay, or in that intervening period they may have conferred with others (which may have led to either memory distortions or source monitoring errors). Future researchers should minimise the time delays between police interview and research interview in order to lessen these effects.

Although the sample recruited was small, it is important to acknowledge that the participants were suspects from a minority community that has been traditionally ones hard to reach for research purposes. However, thematic saturation was evident; therefore, a large sample may have been of little additional benefit. It is important to recognise that the super-ordinate themes presented resulted from the authors' interpretations of the data. Also, it will be important in future studies to compare and contrast the experiences of suspects from different communities to determine the implications of such negative stereotypes in greater detail. 


\section{Conclusion}

The present study found that if police interviewers developed negative stereotypes on the basis of suspects' ethnicity or religion, then this may lead towards discriminatory behaviour when interviewing suspects from out-groups. It is difficult to determine whether such racial/religious stereotypes operate consciously or unconsciously. From a theoretical perspective, unconscious racial stereotyping may provide an explanation for the police interviewers' discriminatory behaviour. Such negative stereotypes are more likely to develop through repeated contacts with an out-group and subsequently guide perceptions in future encounters (Smith \& Alpert, 2007). Given the potential and serious consequences of racial/religious stereotypes which may result in discriminatory behaviour, it is argued that further training of police officers is necessary to make them more aware of the implications of such negative (racial/religious) stereotypes to improve on interviewing performance, case outcomes, and community cohesion. Recognising that the present study concerned suspects from one community (i.e. Asian Muslims), it is clear that there is much work to be undertaken with suspects from different communities before we confidently understand the extent and implications of such negative stereotypes within police interviewing context.

\section{Note}

1. The CPS (Crown Prosecution Service) is the principal prosecuting authority for England and Wales, acting independently in criminal cases investigated by the police and others.

\section{Disclosure statement}

No potential conflict of interest was reported by the authors.

\section{References}

Allport, G. W. (1954). The nature of prejudice. Cambridge, MA: Addison-Wesley.

Awan, I. (2012). 'I am a Muslim not an extremist': How the prevent strategy has constructed a 'suspect' community. Politics \& Policy, 40(6), 1158-1185. doi:10.1111/j.17471346.2012.00397.x

Blaine, B. E. (2012). Understanding the psychology of diversity. London: Sage.

Bowling, B., \& Phillips, C. (2012). Policing ethic minority communities. In T. Newburn (Ed.), Handbook of policing (2nd ed., pp. 528-55). London, UK: Routledge.

Boyatzis, R. E. (1998). Transforming qualitative information: Thematic analysis and code development. London: Sage.

Braun, V., \& Clarke, V. (2006). Using thematic analysis in psychology. Qualitative Research in Psychology, 3, 77-101. doi:10.1191/1478088706qp063oa

Breen-Smyth, M. (2014). Theorising the 'suspect community': Counterterrorism, security practices and the public imagination. Critical Studies on Terrorism, 7(2), 223-240. doi:10.1080/17539153. 2013.867714

Cardwell, M. (2000). The complete A-Z psychology handbook. London: Hodder \& Stoughton.

Clarke, C., \& Milne, R. (2001). A national evaluation of the PEACE investigative interviewing course. London: Home Office.

Clarke, C., Milne, R., \& Bull, R. (2011). Interviewing suspects of crime: The impact of PEACE training, supervision and the presence of a legal advisor. Journal of Investigative Psychology and Offender Profiling, 8, 149-162. doi:10.1002/jip.144

Clements, P. (2008). Policing a diverse society. Oxford: Oxford University Press. 
Crabtree, B., \& Miller, W. (1999). Using codes and code manuals: A template organizing style of interpretation. In B. F. Crabtree \& W. L. Miller (Eds.), Doing qualitative research 2nd ed. (pp. 163177). Thousand Oaks, CA: Sage.

Devine, P. G. (1989). Stereotypes and prejudice: Their automatic and controlled components. Journal of Personality and Social Psychology, 56, 5-18. doi:10.1037/00223514.56.1.5

Ehrlich, H. J., \& Rinehart, J. W. (1965). A brief report on the methodology of stereotype research. Social Forces, 43, 564-575. doi:10.2307/2574464

Findley, K. A., \& Scott, M. S. (2006). The multiple dimensions of tunnel vision in criminal cases. Wisconsin Law Review, Vol. 2, Univ. of Wisconsin Legal Studies Research Paper No. 1023. Retrieved from SSRN https://ssrn.com/abstract $=911240$

Fleiss, J. L. (1981). The measurement of interrater agreement. Statistical Methods for Rates and Proportions, 2, 212-236.

Griffiths, A., \& Milne, R. (2006). Will it all end in tiers? Police interviews with suspects in Britain. In T. Williamson (Ed.), Investigative interviewing (pp. 167-189). London: Routledge.

Hickman, M. J., Thoms, L., Silvestri, S., \& Nickels, H. (2011). Suspect communities' ? Counter-terrorism policy, the press, and the impact on Irish and Muslim communities in Britain: A report for policy makers and the general public. London, UK: London Metropolitan University.

Hill, C., Memon, A., \& McGeorge, P. (2008). The role of confirmation bias in suspect interviews: A systematic evaluation. Legal and Criminological Psychology, 13, 357-371. doi:10.1348/ $135532507 X 238682$

Hillyard, P. (1993). Suspect community: People's experiences of the prevention of terrorism acts in Britain. London: Pluto Press.

Huggon, W. G. (2012). Subtle bias in legal decision making: How attitudes and social norms affect primary and peripheral targets (Unpublished Doctoral dissertation). University of Toronto, Toronto.

Kassin, S. M., Goldstein, C. C., \& Savitsky, K. (2003). Behavioral confirmation in the interrogation room: On the dangers of presuming guilt. Law and Human Behavior, 27(2), 187-203. doi:10.1023/ A:1022599230598

Lynch, O. (2013). British Muslim youth: Radicalisation, Terrorism and the Construction of the 'Other'. Critical Studies on Terrorism, 6(2), 241-261. doi:10.1080/17539153.2013.788863

Maynard-Moody, S., \& Musheno, M. (2003). Cops, teachers, counselors: Stories from the front lines of public service. Ann Arbor: University of Michigan Press.

Miles, M. B., \& Huberman, A. M. (1994). Qualitative data analysis: An expanded sourcebook. London: Sage.

Milne, R., \& Bull, R. (1999). Investigative interviewing: Psychology and practice. Chichester: Wiley.

Minhas, R., Walsh, D., \& Bull, R. (2017). Developing a scale to measure the presence of possible prejudicial stereotyping in police interviews with suspects: The Minhas investigative interviewing prejudicial stereotyping scale (MIIPSS). Police Practice and Research: An international Journal, 18, 132-145. doi:10.1080/15614263.2016.1249870

Mortimer, A., \& Shepherd, E. (1999). Frames of mind: Schemata guiding cognition and conduct in the interviewing of suspected offenders. In A. Memon \& R. Bull (Eds.), Handbook of the psychology of interviewing (pp. 293-315). Chichester: Wiley.

Moston, S., Stephenson, G. M., \& Williamson, T. M. (1992). The effects of case characteristics on suspect behaviour during police questioning. British Journal of Criminology, 32, 23-40.

Pantazis, C., \& Pemberton, S. (2009). From the 'old' to the 'new' suspect community examining the impacts of recent UK counter-terrorist legislation. British Journal of Criminology, 49, 646-666. doi:10.1093/bjc/azp031

Phillips, C., \& Bowling, B. (2003). Racism, ethnicity and criminology. Developing minority perspectives. British Journal of Criminology, 43, 269-290.

Rossmo, D. K. (2006, October). Criminal investigative failures: Avoiding the pitfalls. FBI Law Enforcement Bulletin, Washington.

Smith, M. R., \& Alpert, G. P. (2007). Explaining police bias a theory of social conditioning and illusory correlation. Criminal Justice and Behavior, 34, 1262-1283. doi:10.1177/0093854807304484

Smith, N., \& Flanagan, C. (2000). The effective detective: Identifying the skills of an effective SIO. London: Home Office, Policing and Reducing Crime Unit, Research, Development and Statistics Directorate. 
Snook, D., Cullen, B., \& R. M. (2008). Bounded rationality and criminal investigations: Has tunnel vision been wrongfully convicted. In D. K. Rossmo (Ed.), Criminal Investigative Failures (pp. 71-98). Boca Raton: CRC press.

Stelfox, P. (2009). Criminal investigation: An introduction to principles and practice. Cullompton: Willan. Tajfel, H., \& Turner, J. C. (1979). An integrative theory of intergroup conflict. In W. G. Austin \& S. Worchel (Eds.), The social psychology of intergroup relations (pp. 33-47). Monterey, CA: Brooks/Cole.

Walsh, D., \& Bull, R. (2012). Examining rapport in investigative interviews with suspects: Does its building and maintenance work? Journal of Police and Criminal Psychology, 27, 73-84. doi:10.1007/ s11896-011-9087-x

Walsh, D. W., \& Milne, R. (2008). Keeping the PEACE? A study of investigative interviewing practices in the public sector. Legal and Criminological Psychology, 13, 39-57.

Williamson, T. (2006). Investigative interviewing and human rights the war on terrorism. In T. Williamson (Ed.), Investigative interviewing, (pp. 3-22). London: Routledge. 